SANDIA REPORT

SAND96-2317 • UC-706

Unlimited Release

Printed September 1996
RECEIVED

NoV 061996

OSTI

\title{
A Progress Report on the LDRD Project Entitled "Microelectronic Silicon-based Chemical Sensors: Ultradetection of High Value Molecules"
}

R. C. Hughes

Prepared by

Sandia National Laboratories

Albuquerque, New Mexico 87185 and Livermore, California 94550

for the United States Department of Energy

under Contract DE-AC04-94AL85000

Approved for public release; distribution is urfliniled

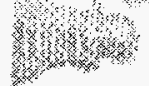

(3)
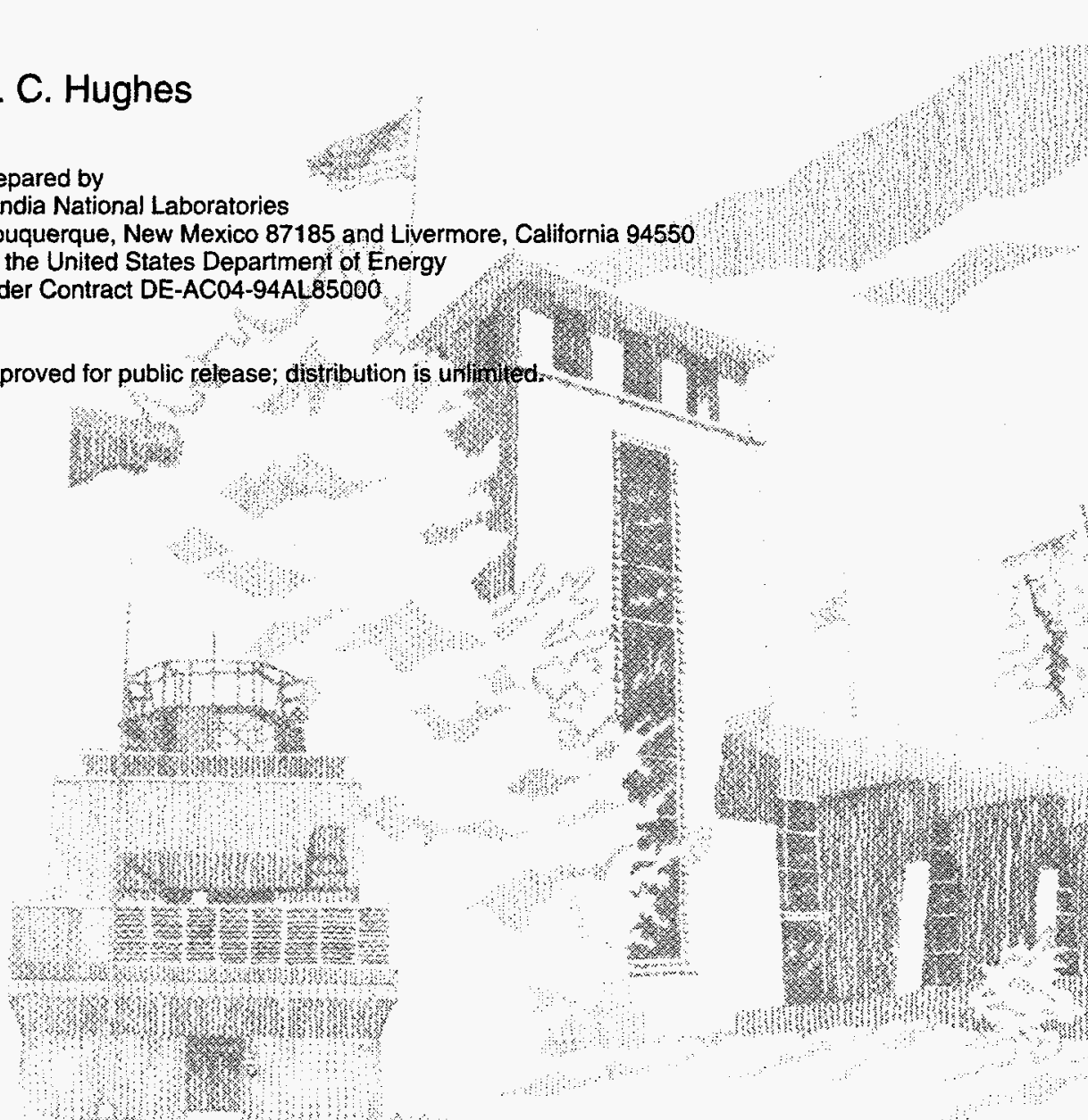

SF29000(8-81) 
Issued by Sandia National Laboratories, operated for the United States Department of Energy by Sandia Corporation.

NOTICE: This report was prepared as an account of work sponsored by an agency of the United States Government. Neither the United States Government nor any agency thereof, nor any of their employees, nor any of their contractors, subcontractors, or their employees, makes any warranty, express or implied, or assumes any legal liability or responsibility for the accuracy, completeness, or usefulness of any information, apparatus, product, or process disclosed, or represents that its use would not infringe privately owned rights. Reference herein to any specific commercial product, process, or service by trade name, trademark, manufacturer, or otherwise, does not necessarily constitute or imply its endorsement, recommendation, or favoring by the United States Government, any agency thereof or any of their contractors or subcontractors. The views and opinions expressed herein do not necessarily state or reflect those of the United States Government, any agency thereof or any of their contractors.

Printed in the United States of America. This report has been reproduced directly from the best available copy.

Available to DOE and DOE contractors from

Office of Scientific and Technical Information

PO Box 62

Oak Ridge, TN 37831

Prices available from (615) 576-8401, FTS 626-8401

Available to the public from

National Technical Information Service

US Department of Commerce

5285 Port Royal Rd

Springfield, VA 22161

NTIS price codes

Printed copy: A03

Microfiche copy: A01 


\section{DISCLAIMER}

This report was prepared as an account of work sponsored by an agency of the United States Government. Neither the United States Government nor any agency thereof, nor any of their employees, makes any warranty, express or implied, or assumes any legal liability or responsibility for the accuracy, completeness, or usefulness of any information, apparatus, product, or process disclosed, or represents that its use would not infringe privately owned rights. Reference berein to any specific commercial product, process, or service by trade name, trademark, manufacturer, or otherwise does not necessarily constitute or imply its endorsement, recommendation, or favoring by the United States Government or any agency thereof. The views and opinions of authors expressed herein do not necessarily state or reflect those of the United States Government or any agency thereof. 


\section{DISCLAIMER}

Portions of this document may be illegible in electronic image products. Images are produced from the best available original document. 
SAND96-2317

Unlimited Release

Distribution

Printed September 1996

Category UC-706

\title{
A Progress Report on the LDRD Project Entitled "Microelectronic Silicon-based Chemical Sensors: Ultradetection of High Value Molecules"
}

\author{
R.C. Hughes, \\ Microsensor R\&D Dept. \\ Sandia National Laboratories, ABQ, NM, 87185
}

\begin{abstract}
:
This work addresses a new kind of silicon based chemical sensor that combines the reliability and stability of silicon microelectronic field effect devices with the highly selective and sensitive immunoassay. The sensor works on the principle that thin $\mathrm{SiN}$ layers on lightly doped $\mathrm{Si}$ can detect $\mathrm{pH}$ changes rapidly and reversibly. The $\mathrm{pH}$ changes affect the surface potential, and that can be quickly determined by pulsed photovoltage measurements. To detect other species, chemically sensitive films were deposited on the SiN where the presence of the chosen analyte results in $\mathrm{pH}$ changes through chemical reactions. A invention of a cell sorting device based on these principles is also described. A new method of immobilizing enzymes using Sandia's sol-gel glasses is documented and biosensors based on the silicon wafer and an amperometric technique are detailed.
\end{abstract}




\section{Introduction:}

The origin of this LDRD project occurred with a chance meeting between a Sandia MTS, Ron Lipinski (9363) and a professor of medicine, Dr. Stuart Kauffman. Kauffman splits his time between the U. of Penn. and the Sante Fe Institute in Sante Fe, New Mexico. Stuart is not a normal practicing $\mathrm{MD}$, but a researcher who specializes in mathematical aspects of genetics and has won a MacArther "genius" award. The technical problem he proposed to Lipinski involved instrumentation for finding organisms that produce or secrete high value molecules (HVM). In special cases, like the genetically engineered organisms that produce human insulin, biotechnology has found a way to cultivate living factories for high value molecules that are robust enough for production in commercial quantities.

But lately a new way of producing high value molecules is being explored by a number of research groups; it is called variously "directed evolution" or "applied molecular evolution". These new biomolecules come from a variety of biochemical synthetic techniques. A summary can be found in a New Scientist review article [1] and a Scientific American report [2]. Dr. Kauffman's inventions in this area include a way to randomize the genes that produce proteins in cells so that a culture of organisms can be grown that produce a very large number of different proteins. Some of these proteins may be the high value molecule you are looking to synthesize, but the problem is that no instrument exists 
that can rapidly find the particular organism that is making the particular protein that you want. Dr. Kauffman believes that the number of different proteins that will be generated by his bugs is about $10^{8}$. Using a normal cell sorting system and sequentially measuring whether the bugs passing through the cell sorter are producing what you want would take a very long time (years).

Both Lipinski and Kauffman came to me for suggestions on how sensor technology might solve this problem. Out of these discussions came a idea for an invention which I have disclosed under the title."Planar Microelectronic Parallel Processing Cell Sorting Device" SD-4971. In 1993 Sandia obtained a waiver of title to this invention from the DOE. This report will describe the invention idea and the experimental steps that have been taken to reduce the invention to practice.

The idea for the instrument came from the knowledge that it would be easy to define $10^{8}$ sensors on the surface of a single Si wafer. After all, Charge Coupled Arrays (CCD's) are routinely fabricated with this sort of density. The question was: how to make $10^{8}$ biosensors and read them out in a relatively efficient manner in a few minutes.

The term "biosensor" has come to mean a class of sensors on electronic platforms that use a biomolecule as part of the transduction method. An example would be a silicon field effect device used as a pH sensor. It has been known since about 1970 that field effect devices without the metal gate are good $\mathrm{pH}$ sensors in aqueous solution. It is only recently that devices based on this principle have become commercially available, but 
they work quite well in hostile environments compared to the old style glass electrode $\mathrm{pH}$ sensors. To make a "biosensor" out of the $\mathrm{pH}$ sensor, a membrane is put over the $\mathrm{pH}$ sensing surface with an enzyme immobilized in it. The most frequently attempted biosensor is one for glucose in blood. The enzyme glucose oxidase(GOX) is widely available and relatively rugged and when it is immobilized in the membrane close to the sensor surface a local $\mathrm{pH}$ change occurs if glucose diffuses into the membrane. This is because the action of the GOX enzyme is to combine glucose with $\mathrm{O}_{2}$ to make gluconic acid and $\mathrm{H}_{2} \mathrm{O}_{2}$. There are many other examples of enzymes used to make a highly selective sensor. The electronic platform could be a pH sensor, an electrochemical sensor or a fiber optic device. A recent symposium gives an overview of the progress being made [3].

This report documents our progress towards the establishment of the technology which would make it possible to find the bugs making the high value molecules. An apparatus was constructed to make it easy to test field effect structures with a variety of chemistries on them. An example of the type of enzyme sensor that can be produced was fabricated.

In order to fully develop the described instrument, a collaboration with the private company who will market it will be necessary. Most likely the company that has the rights to the gene randomizing technology would want the cell sorter to go along with it. We were successful in demonstrating a proof of principle for the high scan rate and the coverage of the whole wafer with the sol-gel Stöber films on which the proper chemistry could be immobilized. 


\section{The Invention.}

In order to perform a proof of principle for the planar cell sorting instrument, I had to perform a series of experiments and first construct a basic biosensor apparatus. The literature has a number of examples of $\mathrm{pH}$ sensors based on insulating surfaces on silicon in which a light probe is used to read out the Si surface potential. The physics behind this technique is straightforward and is akin to a solar cell.

Red light from a focused LED creates electron-hole pairs in the silicon, but not the water or dielectric the light passes through. The light must be pulsed because the insulating layer does not allow a DC current to flow from the silicon. However, the transient current is easy to measure with an oscilloscope. The size of the transient peak depends on the surface potential at the $\mathrm{Si} / \mathrm{SiO}_{2}$ interface. For the n-type $\mathrm{Si}$ used in our experiments, a sufficiently positive surface potential attracts the free, thermal electrons to the surface which eliminates the depletion layer and no photovoltage appears. The surface potential can be scanned to any desired voltage by a voltage supply connected to a reference electrode in the aqueous solution. Fig. 1 shows a block diagram of the apparatus. The aqueous solution must have enough ions in it to be reasonably conductive. The reference electrode makes the electrical contact between the power supply and the water. A Pt wire would also work, but the reference electrode allows the voltage in the water to be defined very accurately, to better than one millivolt, which is necessary for the experiment. The transient current from the light pulse is fed into a special amplifier, either a charge 
sensitive pre-amp or a Keithley current amplifier which must have a fast enough time response to "see" the pulse, which might be as short as 100 nanoseconds. The voltage output of the amplifier is fed into a $\mathrm{AC}$ voltmeter, which averages or integrates the pulse to give a DC output proportional to the transient peak height. We call this signal the "photovoltage".

An example of the data from a typical experiment is given in Fig. 2. The photovoltage is plotted as a function of the voltage from the voltage supply. As expected, as the voltage becomes more negative, the photovoltage increases, resulting in as " $\mathrm{S}$ " shaped response curve. The critical feature of this response is that the curve shifts with $\mathrm{pH}$. The shape remains the same, but the center of the "S" can be used to measure the $\mathrm{pH}$ of the aqueous solution. Displayed in the Fig. are curves for $\mathrm{pH}=7$ and $\mathrm{pH}=3$. The shift is about 50 millivolts per $\mathrm{pH}$ unit.

A photograph of the apparatus is given in Fig. 3. The cell used to contain the aqueous solution has an optical window on one side and a rubber grommeted hole just opposite. A small piece of a $\mathrm{Si}$ wafer can be placed over the hole and a spring loaded electrical contact holds it in place and keeps the aqueous phase from leaking out. It is very important to keep bubbles off the face of the $\mathrm{Si}$ wafer. The backside of the wafer must have an ohmic contact, and the front side (contacting the water) must have a sturdy insulator on it. The silicon wafers that we are using were fabricated under the direction of Brad Smith (1324) in the Sandia Microelectronics Development Lab (MDL). They used 1-2 ohm n-type Si with a Ti-Au ohmic contact. The important insulator consisted of a 
stack with device grade $\mathrm{SiO}_{2}(800 \mathrm{~A})$ grown first into the $\mathrm{Si}$, and then a thick $(1100 \mathrm{~A})$ SiN layer was grown with a chemical vapor deposition (CVD) method. The SiN needed a light HF etch as a post process step to "activate" it for reliable $\mathrm{pH}$ responsiveness. These issues are discussed in the literature of $\mathrm{pH}$ sensing field effect transistors (ISFETs) [4].

A this point we had shown that we could make reliable $\mathrm{pH}$ sensing surfaces that could be probed with a focused light pulse. The biochemistry of the sensor can be counted on to produce a $\mathrm{pH}$ change in the vicinity of the cell. But could we read-out each site $\mathrm{pH}$ fast enough to scan an entire wafer of $10^{8}$ sites fast enough to make a useful instrument? The light pulse generator can easily produce light pulses of 400 nanoseconds duration. Fig. 4 shows the photovoltage response to light pulses this short. Virtually the same dependence as with the longer pulses is found; it would be easy to read-off the $\mathrm{pH}$ of this spot in less than one microsecond.

Optical equipment capable of moving a stage or mirror in steps of 10 microns in one microsecond are commercially available, as is the ability to focus a read light pulse to a 10 micron spot size. The second part of Fig. 4 shows that the SiN surface can respond to $\mathrm{pH}$ changes in a few seconds. Therefore we believe that we have demonstrated that a six inch (standard) wafer could have its entire surface probed for $\mathrm{pH}$ "image" with 10 micron resolution in about 100 seconds. Recording the transient pulse from each 10 micron wide "pixel" would be easy with a multichannel scalar instrument and the whole image could be displayed on a CRT with levels of darkness corresponding to the $\mathrm{pH}$ of each pixel. 
These steps can be performed with commercially available electronic and video equipment.

\section{The Cell Sorter and Its Biochemistry.}

A side view of the cell sorter is shown in Fig. 5. The whole six inch wafer can be placed in a shallow dish containing the aqueous solution and buffer solution with nutrient for the cells (the cells that produce the valuable proteins will be called simply "bugs" for the purposes of this report). The colony of bugs producing a large number of different proteins are spread out on the wafer. The average bug is about 10 microns in diameter. The focused light beam is scanned across the wafer.

Since the intensity of the light affects the photovoltage, a correction scheme for the attenuation of the light by the bugs may be necessary in practice. This can be done by modulating the voltage to create a signal that contains information on the slope of the photovoltage vs. applied voltage curve. Alternatively, light can be brought in from the back of the cell using a modified wafer design. It may also be necessary to isolate one pixel from its neighbors. This would depend on how many minority carriers "leak" from one pixel to ones illuminated just after. This problem could be cured by creating a grid of 10 micron squares on the wafer with ion implantation. The implanted regions would act as a barrier for minority carriers diffusing laterally. This implantation step would not add substantially to the cost of the wafer since it is a process available in most silicon fabrication facilities. 
The pixel where the HVM is being produced would be easily identified by the known position of the light beam. There are commercially available automated pipettes that can be moved to the pixel by a movable stage and pick up the bug or bugs producing the HVM. The valuable bugs can then be multiplied almost endlessly in their own special culture medium and a bug factory can be started to make commercial quantities of the HVM.

The biosensor chemistry is the most difficult part of the project. The surface chemistry must be arranged so that the high value molecule interacts with the surface to produce a $\mathrm{pH}$ change. A simple example would a search for bugs producing urea. A readily available enzyme, urease, converts urea to ammonia which immediately raises the $\mathrm{pH}$ in the vicinity of the bug. The urease enzyme can be immobilized in a membrane that has been previously deposited on th whole six inch wafer by a process like sol-gel coating or spin coating. Thus the task of creating $10^{8}$ biosensors is reduced to a single batch process step. Single pixel biosensors for urea using this scheme have been reported in the literature [4], but unfortunately urea is not a high value molecule. For each family of high value molecules, a new biosensor chemistry must be developed. The chemistry can be tested with a single pixel biosensor such as one described in the invention section. 


\section{The Biosewsor Chemistry}

There are a number of ways to attack the biosensor problem once the high value molecule (HVM), which will probably be a protein that has medicinal properties. The assumption is that there is an expensive process for obtaining this molecule so that it will have been tested and proven to be high value. This also means that there is enough of the HVM to use for deweloping an immuno-assay for the HMV. Many companies are involved in developing immunoassays for a variety of molecules, and the many schemes that are used can be found in textbooks. One scheme that we think would be promising is called the "EMIT" standing for enzyme multiplied immunoassay.

The EMIT has been used for many years, so that the patent on it has expired. Prof. Ken Hunter ( $U$ of Nevada at Reno) and I had an idea for exploiting the EMIT concept on a field effect transistor to make an unattended biosensor for nerve gas and other molecules of interestit. We disclosed this invention in a Sandia disclosure entitled "Method for Ultradetection of Molecules using Immuno-Field Effect Transistors" SD-4956. A patent application has not yet been filed from this disclosure. The virtue of the EMIT assay for this application is that it does not require a manual washing step.

The most popular immunoassay technique, called the ELISA, requires that the fluid be exposed a specially prepared substrate or slide and after an incubation time during which the molecule to be tested for (analyte, e. g. cocaine) has combined with some 
antibody sites on the slide, the excess analyte must be washed away and another reagent solution added to the slide. This new batch of reagent only interacts with sites on the slide that have the analyte attached to the fixed antibody; this will typically be a small percentage of the total available sites, but will be roughly proportional to the original analyte concentration. The new reagent will have an enzyme or radiolabel attached to the antibody and the ones that attached to the fixed antibody/analyte complex will then be detected after the free ones are washed away. This kind of assay has been demonstrated on a pH sensing silicon surface, but the washing steps would be difficult or impossible in the cell sorter application because it would wash away the bugs.

The EMIT could work for the cell sorter in the way shown in Fig. 6. In this Fig., adapted from Ref. [5], the analyte is referred to as the "hapten" which is a term used by biochemists for a small molecule like cocaine. The assay works because there is a competition between the antibody for the hapten (in our case the HVM) for binding on the HVM-enzyme conjugate and the free HVM being produced by the bugs. The HVMenzyme conjugate has been immobilized on the SiN surface in a sol-gel film or polymer gel just like our urease example. It is usually the case that the antibody will be slightly more attached to the free HVM in solution being produced by the bug than to the immobilized conjugate. The antibody would, of course, ignore proteins of other kinds being produced by other bugs. When the antibody releases from the attached enzyme, that enzyme is free to engage in enzyme catalysis; if it were urease, we would put urea in the whole solution. The ammonia would be produced only in the vicinity of the bug producing the HVM. 
Developing an immunoassay of this kind requires the dedicated effort of skilled professional biochemists. There may be many tricks required to obtain the best antibody/HVM/enzyme combinations so that the competitive assay detects low concentrations of HVM. One interesting route to valuable medical products might come from the fact that many new drugs work by inhibiting certain enzymes. The inhibition occurs when a receptor site in the enzyme is occupied by the drug molecule. It is estimated that there are 3000 known and isolated receptor sites in biochemistry, but molecules for inhibition are known for only a few. Thus a biosensor constructed to contain that receptor site would be ideal for searching for the molecule that would cause inhibition. For example, if the enzyme produces a acid product from some substrate (like glucose oxidase on glucose), then the bugs producing a molecule (most probably a protein) that inhibits the enzyme by blocking its receptor, would be easily located by our chip sensor. In this case it would not be necessary to know what the HVM is before constructing the biosensing chemistry.

\section{The Immobilized Enzyme Conjugate}

At the time of this report we do not have an industrial partner for developing this instrument. In order to focus sufficient resources to develop an immunoassay for a particular molecule, I believe the industrial partner would have to have a proprietary interest in that molecule and probably the rights to the patent for the culture of "bugs" which might have "the" bug that is producing the HVM. We at Sandia do not have the 
focused interest in such a molecule. However, we do have a long term interest in molecules involved in weapons of mass destruction, like nuclear weapons, and chemical and biological warfare. Single pixel biosensors for some of these molecules are of great interest and so the rest of LDRD program focused on developing the technology to immobilize enzymes for biosensors, which would be useful for single biosensors and the cell sorter.

\section{Enzyme Immobilization on Sol-Gel Glasses}

Sol-gel films with various pore sizes made from spherical particles of sizes 20,45 and $95 \mathrm{~nm}$ were deposited on the $\mathrm{SiN}$ films on our devices. The devices were read-out in our light addressable potentiometric (LAPS) system looking for the $\mathrm{pH}$ dependence of the surface potential. It was found that the smaller pore sizes had a much weaker $\mathrm{pH}$ dependence than the $95 \mathrm{~nm}$ sol-gel. The larger size was then chosen for use in a new scheme for immobilizing enzymes. In collaboration with Prof. Ken Shea at UC Irvine and Doug Loy of 1812, glucose oxidase was immobilized in the thin film gel on our device surface. This is the first time this method has been used for immobilizing enzymes. This new collaboration has given us optimism that improved immobilization methods will be found for a variety of enzyme based chemical sensors. The fact that we know how to control pore size means that the pores can be tailored to keep the enzyme in a pocket without leaching out. If the pores are large enough the analyte molecules can diffuse quickly in and out as well as the product molecules of the enzyme 
reaction. This process gets to the core of making better enzyme based chemical sensors: the enzyme must not be bound too well to the support (in this case the porous sol-gel film) or the enzymatic reaction will not work. However if the enzyme is too free it will diffuse away from our sensor surface (in this case the $\mathrm{SiN}$ ) and the sensor response will drop with time.

There have been many methods tried for immobilizing enzymes on surfaces, but any new method with better properties will have immediate impact on the field, since current methods suffer from the problems discussed above. In order to make sure that the enzymes being used in the immobilization were chemically active, an apparatus was constructed for the homogeneous assay of glucose and dissolved oxygen. An electrochemical oxygen electrode (Clark electrode) and miniature $\mathrm{pH}$ sensor (UniFet) were immersed in buffered solutions and measured amounts of glucose oxidase, catalase and glucose were added by pipettes. The time dependence of oxygen consumption and $\mathrm{pH}$ change allowed us to measure the activity of the enzymes. The first sensors could detect glucose, but the membranes were too thin to maximize the signal. The signal magnitude and time response of the sensor depends on reactant diffusion rates in and out of the sol-gel films, as well as buffer capacity. 


\section{Modeling of Sensor Response.}

After our initial successful data on immobilized enzyme films based on Sandia's Stöber spheres, we undertook an exercise in modeling the response of the sensor. The important parameters in the model include 1)the enzyme kinetics with the usual Michaelis-Menten form tells us how the enzyme turns over product depending on the concentration of analyte (substrate=glucose). 2) the diffusion of the analyte into the film and the diffusion of the products $\left(\mathrm{H}_{2} \mathrm{O}_{2}\right.$ and gluconic acid) to the sensor surface and also out of film. The diffusion problem greatly complicates the mathematical solution to the sensor response and in fact numerical solutions are required for the complete sensor response versus analyte concentration curve. However analytical solutions with several approximations are possible for the extremes of low concentration and very high concentration. For the cell sorting application we found that an interesting limit occurs. If the area under each bug is about 10 microns square, the number of inhibited enzymes is only about 1000 . It is easy to achieve the high concentration limit for the substrate (for example, glucose). In this limit we find that the sensor pixel response goes as the square of the membrane thickness divided by the diffusion constant for the gluconic acid. Thus thicker films will help the device sensitivity. The calculations show that we should be able to detect about $10^{4}$ high value molecules in each pixel. Other modeling results were obtained for the sensor using amperometric detection. 


\section{Sol-Gel Immobilized enzymes on Amperometric Sensors}

An important application for the sol-gel/Stöber porous films is in the fabrication of miniature wire sensor electrodes for glucose sensing in blood and other media. We teamed with Prof. Wilkins of the UNM Chemical Engineering Dept. for this study. They have considerable experience in fabricating enzyme based glucose sensors on small Pt wires. They detect the $\mathrm{H}_{2} \mathrm{O}_{2}$ produced when glucose encounters the GOX enzyme which has been immobilized in the surface of the Stöber spheres which we deposit on the wire. The Stöber films have several advantages over conventional polymer membranes for immobilizing enzymes. The are very durable and do not delaminate from the $\mathrm{Pt}$ wire when $\mathrm{O}_{2}$ is produced at the wire surface. The diffusion constants appear to be very high. The response of the sensors is very good and we are in the process of analyzing the data from a series of different controlled porosity films. A paper on this work has been accepted by the Journal Analytical Letters and appears in Appendix A.

\section{Acknowledgements.}

I would like to thank Carol Ashley for the preparation of the Stöber glass films and Doug Loy and Ron Lipinski for many helpful discussions. 


\section{References}

1. R. Lewin, New Scientist 12/8/90 pg. 30. "The Universal Constructor Set".

2. Scientific American, 10/90, pg. 18. "New Order: Artificial evolution creates proteins nature missed".

3. "Diagnostic Biosensor Polymers", ACS Symposium Series, \#556, A. M. Usmani and N. Akmal Eds. 1994.

4. B. H. van der Schoot and P. Bergveld, Biosensors 3, 161 (1987/88). "ISFET Based Enzyme Sensors”.

5. D. Monroe, Anal. Chem. 56, 921A (1984), "Enzyme Immunoassay". 


\section{Figure Captions}

1. Block diagram of apparatus used to measure $\mathrm{pH}$ on a silicon chip with a pulsed light source.

2. Bias dependence of photovoltage from apparatus as a function of two different $\mathrm{pH}$ solutions. The DC bias is applied to a reference electrode.

3. The cell used in the biosensor apparatus. This front view shows the window through which the pulsed light is shown. The liquid phase is easily seen and the dark circle at the back is the $\mathrm{pH}$ sensitive surface of the silicon chip. The diameter of the exposed area is about $1 \mathrm{~mm}$. The miniature reference electrode from Bio Rad Laboratories, Cambridge, MA is seen with the wire protruding from the top of the cell. The electrical contact to the back of the silicon wafer is not visible.

4. Data similar to that shown in Fig. 2 only with $400 \mathrm{~ns}$ light pulses. Solution was a pH=7 buffer.(A). (B) shows the time response to a step in $\mathrm{pH}$ from $\mathrm{pH}=7$ to $\mathrm{pH}=3$ caused by an injection of strong acid.

5. Side view of proposed Cell Sorter showing the bugs producing high value molecules (HVM). On a six inch silicon wafer as many as $10^{8}$ different sites could be distinguished. 
Apparatus for Measuring pH on Chip

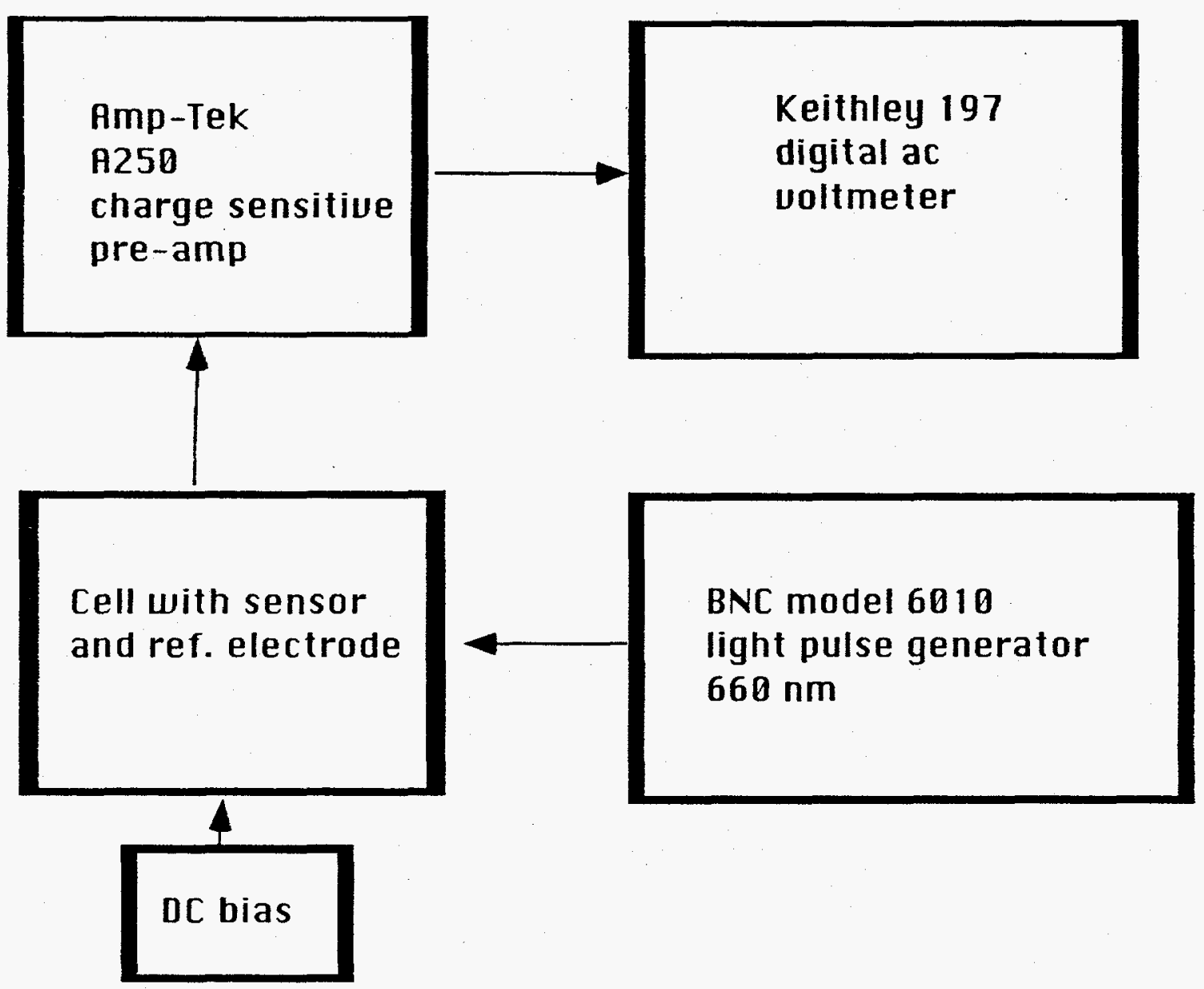




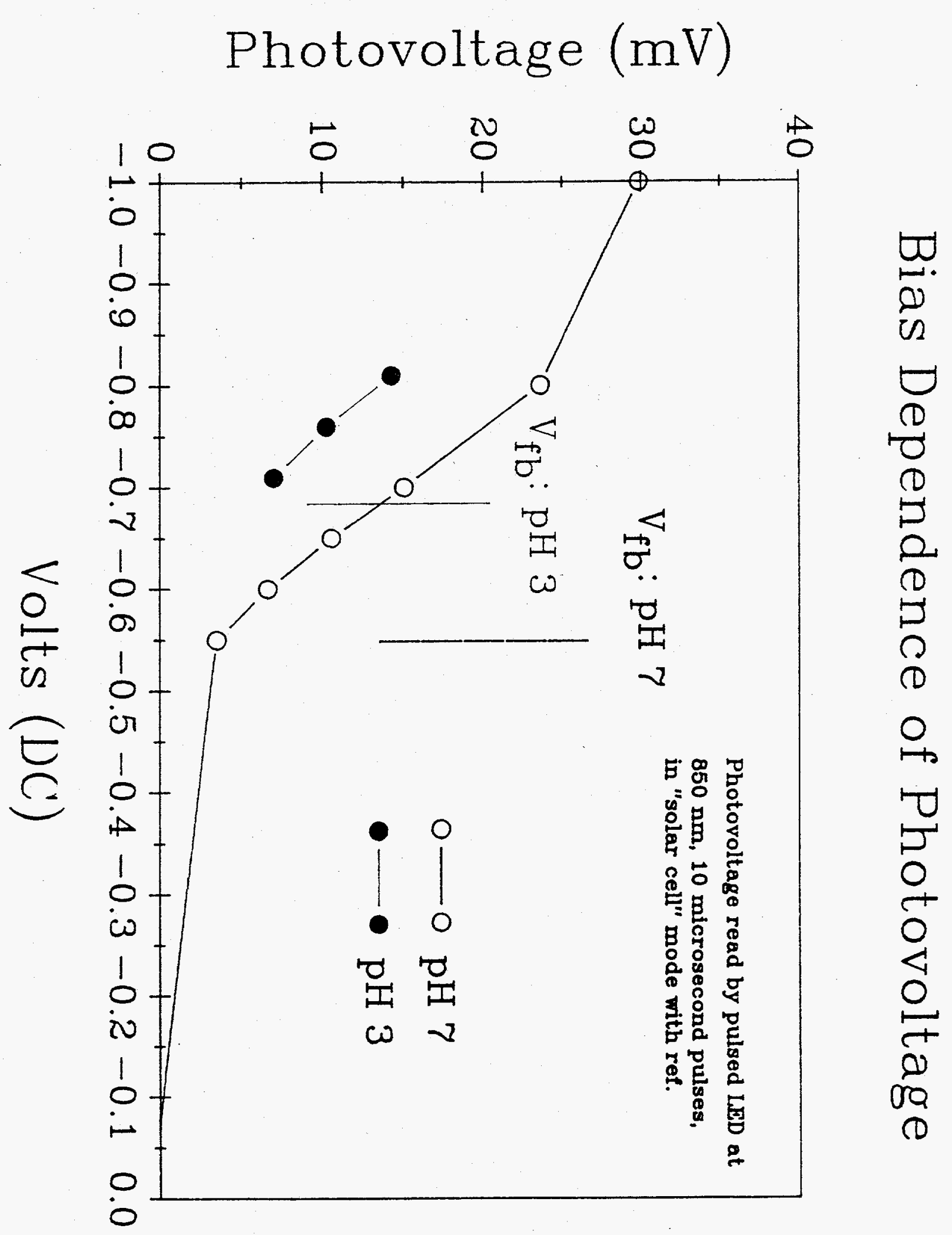




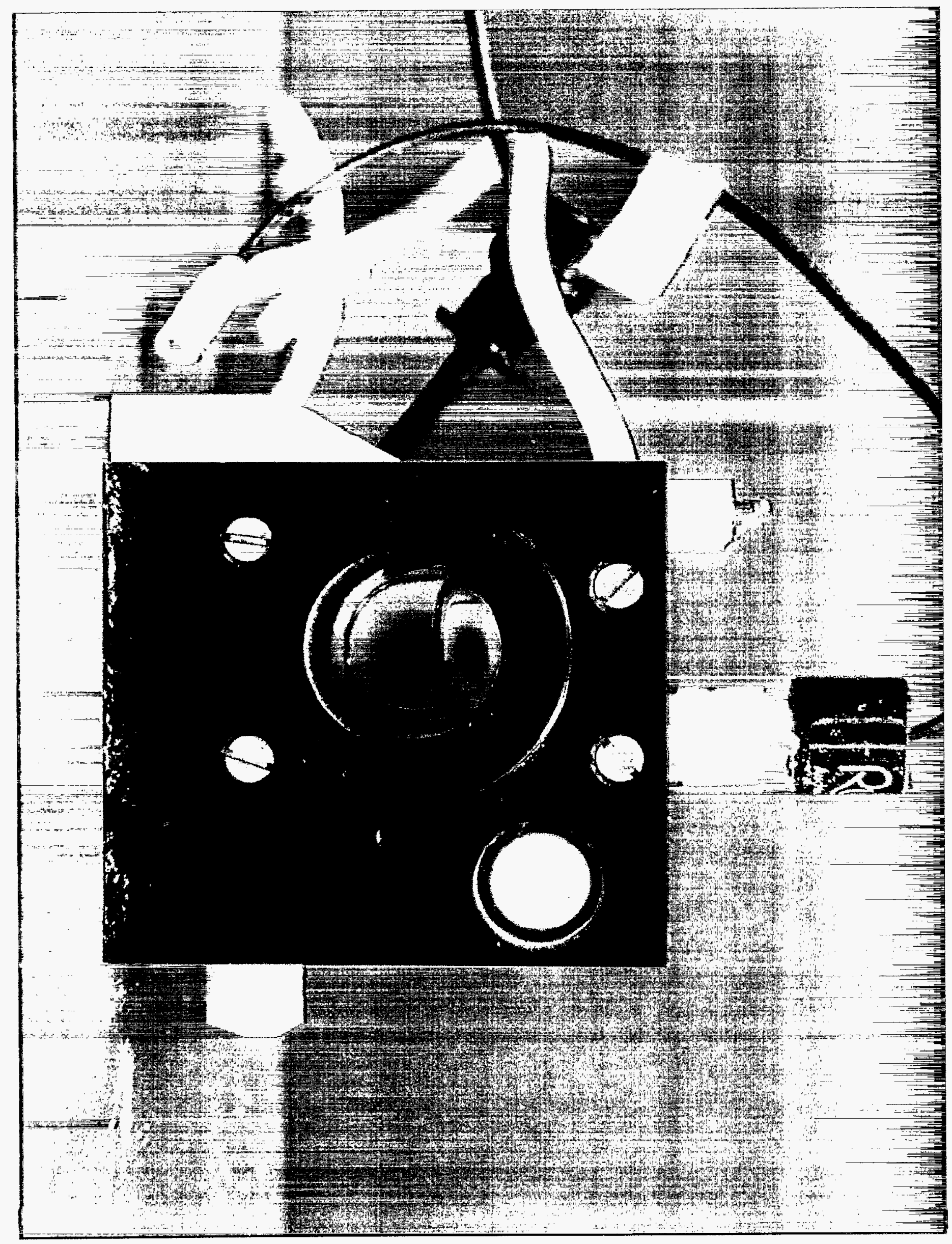



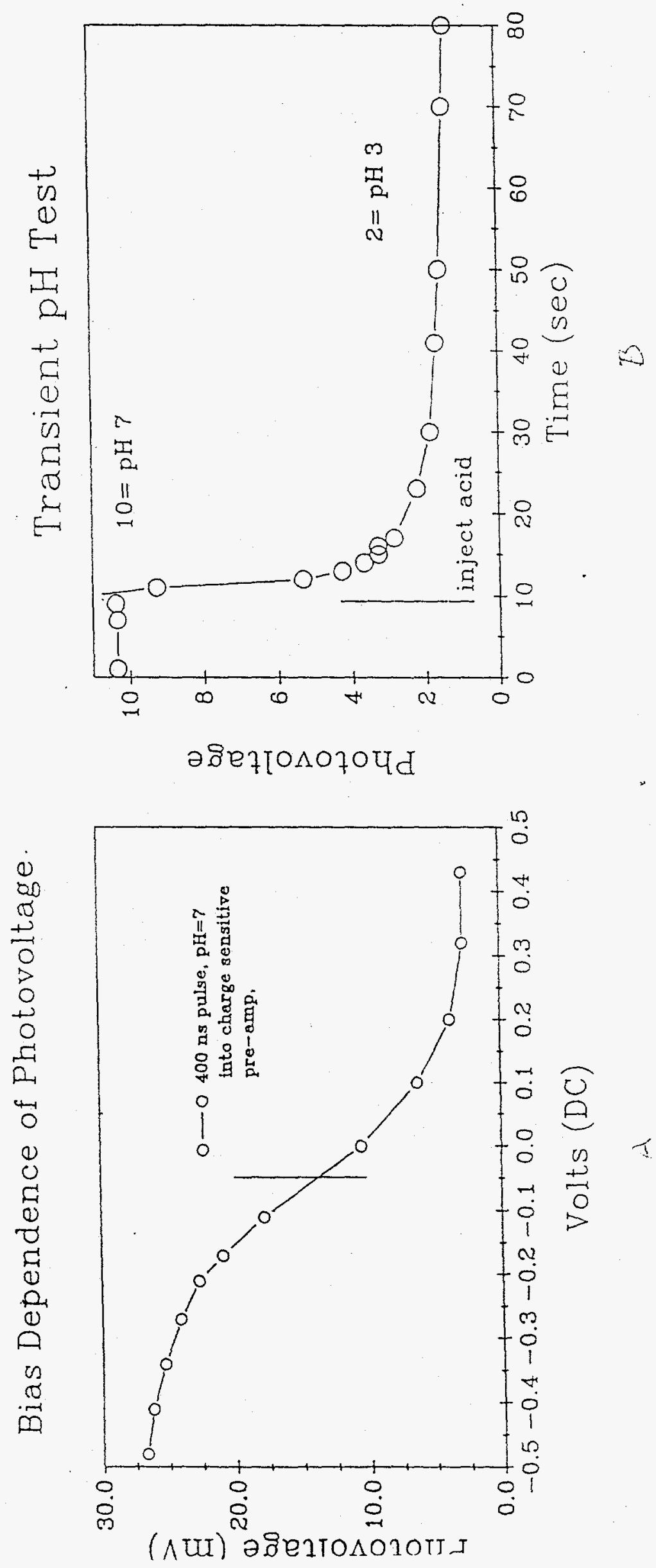


\section{Array Sensor on Silicon Wafer}

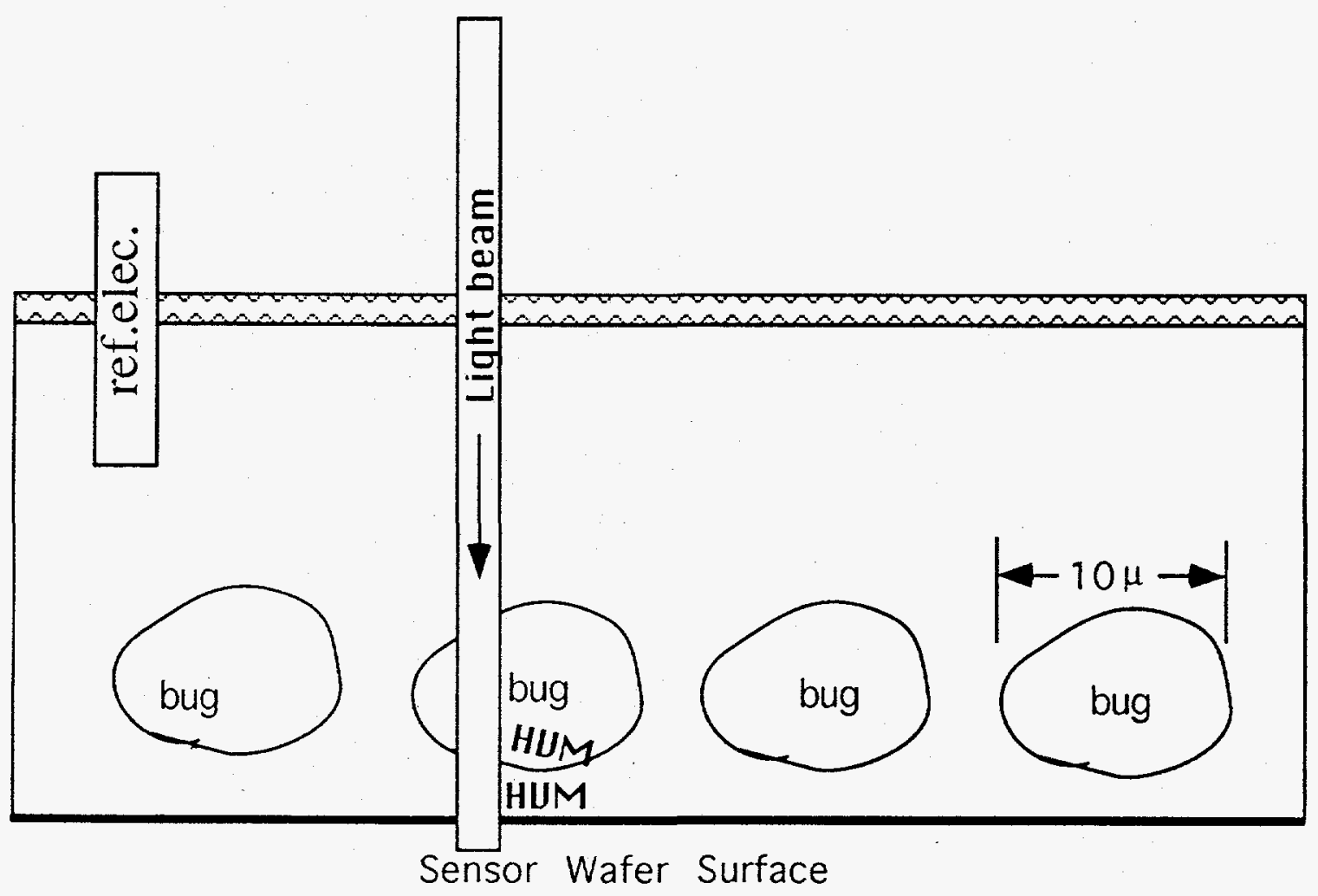

HUM = High Value Molecule 


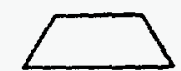

Compound to be messured (hapten)

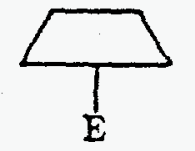

Enxyme-labeled compound

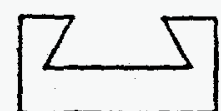

Antibody specific for compound being measured

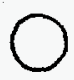

Enzyme-specific chromogenic oubstrate

Tho besic test principles are involved in the EMIT assay: (1) The enzyme must retain enzyme activity after hapten or compound conjugation.<smiles>[C+]C1CCCC1[C+]1CC[C@@H]1C</smiles>

Lizyme Histen Hapten-enzyme conjugate

(Active enzyme)

(2) The enzyme activity of the hapten-enzyme conjugate is reduced or inhibited when the hepten rescts with its specific antibody.

(Active enzyme)

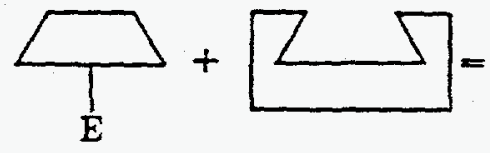

Hapten-nzyme Antibody conjugate

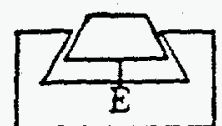

Antibody-bound

hapten-enzyme conjugate

(Inactive enzyme)

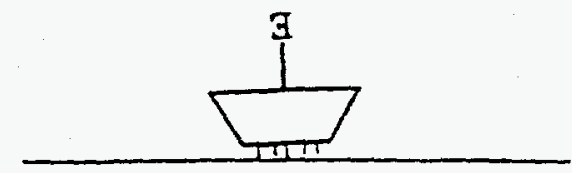

CHEMFET

Enzyme labeled compound immobilized on CHEMFET

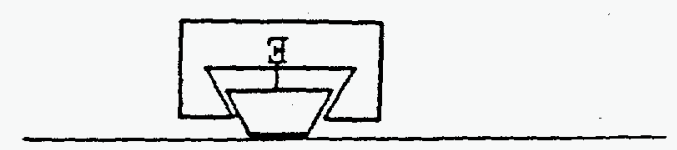

Enzyme labeled compound inhibited by antibody 


\section{Appendix A:}

A manuscript accepted for publication by Analytical Letters entitled:

"Enzyme Electrodes With Gucose Oxidase Immobilized On Stober Glass Beads", Q. Yang, P. Atanasov, E. Wilkins (all UNM Dept. of Chem. E) and R. C. Hughes, accepted in Analytical Letters. SAND 95-1230J. 


\section{INTRODUCTION}

The development of sensors for invasive glucose monitoring has been the focus of much research during the past decade. This attention arises from the clinical importance of these sensors, specially in the management of diabetes 1 . Amperometric enzyme electrodes present the most common approach because of the high substrate specificity and activity of enzyme, and the proportionality of the current signal to glucose concentration provided by amperometry. The oxidation of glucose by molecular oxygen to form gluconic acid and hydrogen peroxide, which is catalyzed by Glucose Oxidase (GOD), forms the basis of glucose detection.

- Needle-type glucose sensors based on hydrogen peroxide electrodes have been the most attractive approach because of their ease of fabrication and adequate performance for short term implantation $2-4$. Success with this approach has reached the stage of implantation 5,6 .

Several techniques have been developed for the immobilization of enzymes. Previous work focused mainly on organic matrixes 7 , but now more and more attention is being paid to the inorganic materials, as such matrixes have a number of advantages over organic ones: resistance to microbial attack; resistance to change in swelling and porosity with $\mathrm{pH}$, and the excellent storage stability of enzymes.

Sol-gel is a low-temperature technology for the production of ceramic materials through the formation of colloidal suspension of metal oxides 8 . This technology and the associated sol-gel doping technology provides an attractive method for immobilization of bio-molecules in the silica gel because of the low temperatures involved in the preparation. Avnir et al demonstrated that it is possible to immobilize organic compounds in inorganic supports by introducing the organic compounds with the polymerization precursors. Indeed, this new class of 
organic-inorganic materials has found a plethora of diagnostic10 and other applications 11 . Braun et al 12 demonstrated the possibility of protein immobilization in sol-gel silica matrices.

Enzyme immobilization on sol-gel silica supporting matrix can be by adsorption, entrapment, or cross-linking. Much of the work has used the physical entrapment method. Several leading research groups in this field $9.11,13,14$ have used cyclic voltammetry to study the activity of GOD doped within a tetramethoxysilane (TMOS) - derived sol-gel matrix. In this scheme the sol-gel was doped with GOD and a mediator, hydroxymethyl ferrocene. This mixture was then coated onto the distal end of a glassy carbon electrode. Enzyme activity was estimated to be $70-80 \%$ in the fresh polymeric silica sol, but no information on the activity as the coating aged was provided. Glezer et al 15 reported a new class of enzyme electrodes made of conductive, porous vanadium pentoxide prepared by the sol-gel doping procedure. Cyclic voltammetry was used as the mode of detection for glucose. The metrological characteristics of the vanadium oxide biosensors such as the range and sensitivity of detection are similar to those of commercial glucose electrodes. Saturation of signal was observed beyond $10 \mathrm{mM} \mathrm{B-D-glucose.} \mathrm{The}$ calibration curve of the vanadium pentoxide biosensor was stable during prolonged storage, and the electrode did not lose any activity during 10 days of storage at $4^{\circ} \mathrm{C}$. Tsionsky et al 16 introduced sol-gel-derived ceramic-carbon composite electrodes. These electrodes are rigid, porous, easily modified chemically and have a renewable external surface. The electrodes offer higher stability than carbon paste electrodes, and are more amenable to chemical modification than monolithic and (organic) carbon electrodes. Tatsu et al17 prepared tetraethoxysilane (TEOS) - based sol-gel monoliths doped with GOD and reported on their performance as glucose-sensing elements. In a flow injection analysis scheme, the monolith-based sensor exhibited 
a peak response time on the order of $4 \mathrm{~min}$. Saturation of the signal response was observed over $400 \mathrm{mg} / \mathrm{dL}$, and the GOD activity was shown to vary over time, depending on the actual storage temperature. With increase in aging temperature, the yield increased but the activity decreased. The activity of the entrapped GOD was found to be 20 -fold greater when stored at $-20^{\circ} \mathrm{C}$ compared with room temperature. The sol-gel-encapsulated GOD was reported to remain active for at least 2 months when stored desiccated at $4^{\circ} \mathrm{C}$.

Dvorak \& Armond 18 described some examples of electrode modification by a sol-gel silicon dioxide gel film doped with trisruthenium (II) chloride, which retained its electrochemical activity and exhibited an anodic photoeffect. The comparison of photochemical and electrochemical data was used to estimate the active fraction of the encapsulated complex.

Braun et al 19 reported on the properties of a $8 \times 2 \mathrm{~mm}$ disk of tetramethyl orthosilicate-derived xerogel doped with glucose oxidase, peroxidase, and a chromogenic dye for detection of glucose. This disk-based device did indeed respond to glucose, but information on enzyme activity, stability, detection limits, and response time were not presented.

The approach used in this study is based on exploiting chemical reaction between primary amino groups from the silanization process on the support material and the amino group on the enzyme. The two terminal aldehyde entities of glutaraldehyde cross-link the two amino groups on the support material and the enzyme. In this reaction water is eliminated and Schiff-base type of bonds $\left(\mathrm{R}_{\mathrm{i}} \mathrm{N}=\mathrm{CHR}_{\mathrm{j}}\right)$ are formed:

$$
\begin{aligned}
& -\mathrm{H}_{2} \mathrm{O} \\
& \text { [Support] }-\mathrm{NH}_{2}+\mathrm{OHC}-\left(\mathrm{CH}_{2}\right)_{3}-\mathrm{CHO} \rightarrow-.-\mathrm{S} \text { Support]-N }=\mathrm{CH}-\left(\mathrm{CH}_{2}\right)_{3}-\mathrm{CHO} \\
& -\mathrm{H}_{2} \mathrm{O}
\end{aligned}
$$

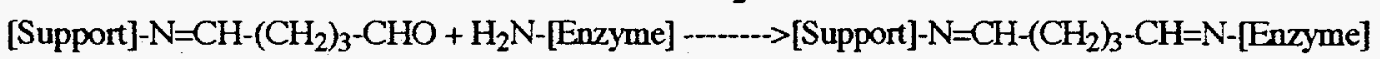


In this way, the glutaraldehyde actually acts as a cross-linking agent which fastens the enzyme chemically to the solid support. The support can have inherent amino groups as in the case of Nylon, or have some added by suitable pretreatment. Thus, silanization with 3-amino-propyltriethoxysilane is of ten used for the glass bead surface preparations.

\section{EXPERIMENTAL}

\section{$\underline{\text { Reagents and Materials }}$}

Glucose Oxidase (GOD, E.C.1.1.3.4, activity 250 EU.mg-1, from Aspergillus Niger was from Sigma Chemical Co.(St. Louis, MO), and used without further purification. Platinum wires of $0.127 \mathrm{~mm}$ diameter were from Aldrich Chemical Co., Inc. (Milwaukee, WI). 3-Aminopropyltriethoxy silane , glutaraldehyde (25\%) and $B-D(+)$-Glucose were from Sigma Chemical Co., the glucose was used as a stock solution $(20 \mathrm{~g} / \mathrm{L})$ in phosphate buffer. All other reagents used were of analytical grade. Distilled water was used in all the experiments.

Blood plasma was prepared by centrifugation of heparinized fresh bovine blood, obtained from a local slaughterhouse. Glucose concentration in the different plasma samples was measured by standard clinical methods using a B-Glucose Analyzer (HemoCue AB, Angelholm, Sweden).

\section{Sensor Preparation}

Platinum wires were coated with a layer of Stöber glass beads by sol-gel technology using the facilities of Sandia National Laboratories. The porous Stöber glass films were made by multiple dip coating of $\mathrm{Pt}$ wires according to a previously published method 20. After each dip the wires were cured at $400^{\circ} \mathrm{C}$ in air. The 
monodisperse glass spheres were made by the Stöber method 21 and maintained in ethanol-water ( $\mathrm{pH} 11$ ) solutions. Films made in this manner have a very high free volume and porosity. The perceived advantages of using Stöber glass films for immobilizing bioactive molecules such as enzymes include the rigid structure of the films, strong adhesion to the sensor surface (both $\mathrm{pH}$ sensing surfaces like SiN and the Pt wires have been fabricated), and high potential diffusion constants for both reactants and products. Other films, both organic polymers and inorganic sol-gel matrices, enmesh the biomolecules in a gel where diffusion constants can be lowered by factors of up to $10^{3}$. It is known from BET type porosity and surface area measurements that Stöber films made from different size spheres have a well defined and reproducible porosity of $37 \%$, which is larger than one would expect from close packing of the spheres.

Table 1. gives the parameters of the platinum wires coated with different sizes of Stöber glass beads. The thickness of the coating layer of Stöber glass beads in every case is close to $1.4 \mu \mathrm{m}$. The diameter of the glass beads used in the experiments ranged from $20 \mathrm{~nm}$ to $100 \mathrm{~nm}$.

TABLE 1. Parameters of the glass beads coated on the platinum electrode

\begin{tabular}{lcc} 
Diameter $(\mathrm{nm})$ & Thickness $(\mu \mathrm{m})$ & Number of Coats \\
\hline 20 & 1.34 & 6 \\
45 & 1.84 & 5 \\
70 & 1.36 & 5 \\
100 & 1.48 & 9
\end{tabular}


Fig. 1 shows SEM photographs of the Stöber glass beads layer coated on platinum wires. From the Figure it can be seen that the bead distribution becomes more homogeneous as the glass bead diameter increases. The coatings with $20 \mathrm{~nm}$ and $45 \mathrm{~nm}$ Stöber glass beads on the platinum electrode surfaces demonstrate some cracks. The cracks on the electrode coated with $20 \mathrm{~nm}$ beads are larger than that observed on the electrode coated with $45 \mathrm{~nm}$ Stöber glass beads.

The cracks on the surface, if not eliminated, would result in a manufacturing process that would not yield identical biosensors. Thereafter, the bare platinum exposed via the cracks can oxidize other substances present in the medium and therefore increase interference effects. One of the sensors was a bare platinum wire and was used as a control.

Fig. 2 shows the schematic of the electrode construction. The electrode consists of a platinum wire, a Stöber glass beads coating layer on the platinum, and the outer immobilized enzyme layer. The glass coating layer has two effects: it acts as a support and matrix for the enzyme; it can be a barrier to some substances that may cause disturbance in the signal.

Silanization was utilized to prepare the Stöber glass beads and the platinum wire surfaces to bond with glutaraldehyde. Solution of 3-aminopropytriethoxy silane $(0.2 \mathrm{~mL})$ in distilled water $(2 \mathrm{~mL}$, to give a $10 \% \mathrm{v} / \mathrm{v}$ solution) was prepared. The $\mathrm{pH}$ was adjusted to 4.1 using hydrochloric acid (HCI) solution. This mixture was subsequently placed into a small vial and the five electrode immersed into the vial. They were kept in an oven at $80^{\circ} \mathrm{C}$ and shaken every fifteen minutes for three hours. The sensors were rinsed completely in distilled water and then dried at $120^{\circ} \mathrm{C}$ for three hours. The wires were stored in the refrigerator for 24 hours.

Immobilization was accomplished by first creating a layer of glutaraldehyde bonded to the silanized electrode surface. A $2.5 \%$ glutaraldehyde solution was made with $27 \mathrm{~mL}$ distilled water and $3 \mathrm{~mL}$ of $25 \%$ glutaraldehyde. Immobilization 
was accomplished by immersing the wire in the glutaraldehyde solution, continuously stirred, for one hour at room temperature. The wires were then rinsed with water for one hour at room temperature after that the electrodes were immersed in the enzyme solution. The enzyme solution was prepared with $80 \mathrm{mg}$ of glucose oxidase in $2 \mathrm{~mL}$ phosphate buffer of $\mathrm{pH}$ 7.4. The wires were left in the enzyme solution overnight at $4^{\circ} \mathrm{C}$ to allow immobilization onto the glass layer.

\section{Apparatus and Procedure}

A three-electrode electrochemical cell was used to test the sensors. This system used a bare platinum electrode as a counter electrode, the glass coated enzyme electrode as a working electrode, and a silver/silver chloride electrode as a reference (standard) electrode.

Cyclic voltammetry and constant potential amperometry experiments were performed using a potentiostat (Bipotentiostat Model AFCBP1 Pine Instruments Co., Grove City, PA) which was connected to a recorder ( Model $200 \mathrm{XY}$ Recorder, The Recorder Company).

Experiments were carried out in a thermostated electrochemical cell with a volume of $25 \mathrm{~mL}$. The concentration of solution in the cell was varied by consecutive additions of glucose. Phosphate buffer solution ( $\mathrm{pH} 7.4$ ) was used as a supporting electrolyte. During the experiments the solution in the cell was continuously agitated by a magnetic stirrer.

\section{RESULT AND DISCUSSION}

Cyclic voltammograms were obtained in order to estimate a working potential for the prepared electrodes. The cyclic voltammograms recorded at several glucose concentrations showed an increase of the current in the potential range of 
hydrogen peroxide oxidation. This indicates that the biosensing mechanism is via hydrogen peroxide oxidation (generated by enzyme oxygen reduction). In glucose solutions, a significant increase of the anodic current at potentials more positive than $+0.35 \mathrm{~V}$ occurred. In these cases the anodic current reached an observable plateau at potentials more positive than $+0.55 \mathrm{~V}$. The current value in the plateau range increased with the increase of the glucose concentration. From the cyclic voltammetry studies a working potential of $+0.6 \mathrm{~V}$ was chosen, and all sensors were operated polarized at this potential during the constant potential amperometry.

\section{Performance of The Glucose Sensors}

Fig. 3.a shows the calibration curves obtained initially after the immobilization process. From the Figure it can be seen that the signal depends on the size of the glass beads. The size of the glass beads affects the surface and pore distribution of the bead matrix and hence influences the amount of enzyme immobilized. The signal amplitude at given glucose concentration increases with decrease in the radius of the beads in the glass coating layer from $100 \mathrm{~nm}$ to $20 \mathrm{~nm}$. Platinum wires which had no glass coating, but had the enzyme immobilized on the silanized surface responded with the largest signal. This is a result of the lack of diffusion-barrier for the diffusion of glucose and hydrogen peroxide to and from the electrode.

The response time of the electrodes (estimated as time to reach $95 \%$ of the steady state value of the sensor current signal ) was about $1.5 \mathrm{~min}$. This time was not affected by the radius of the glass beads in the coating layer.

Fig. 3.b shows the data from Fig. 3.a in the Eadie-Hof tsee coordinates (electrode signal vs sensitivity). This plot is a linearization of the Michaelis-Menten equation and it can be used as an evaluation tool for enzyme electrode behavior. It can be seen from Fig. 3.b that the calibration curves data (from Fig. 3.a) are 
linearized to fit linear dependencies in the Eadie-Hof tsee coordinates characterized with negative slopes. From this slopes the apparent Michaelis constant of the electrode process can be calculated. The slopes of the Eadie-Hof tsee plot (Fig. 3.b) are almost the same. From the plot, an apparent Michaelis-Menten constant of 130 $\mathrm{mg} / \mathrm{dL}$ is obtained. Since the external diffusion of glucose is fast compared to the rate of the reaction, the process was under the control of kinetics of the reaction.

The sol-gel process 22 of fers many strategies for the preparation of inorganic materials with pore sizes in the range appropriate for membranes and sensors, and allows thin films to be fabricated using simple procedures. Although the deposition of particulate sols appears well-suited to the preparation of the inorganic membranes, problems associated with cracking, phase, and grain growth so far have thwarted attempts to prepare defect-free, supported membranes with the small pore sizes required to achieve molecular sieving. These techniques need further improvement.

Direct oxidation of glucose on the platinum surface even in the absence of glucose oxidase can be another reason for such behavior. The increase of the oxidation signal of the electrodes coated with $100 \mathrm{~nm}$ beads was higher than that for the electrodes coated with $20 \mathrm{~nm}$ beads. Because of the surface cracks (seen on Fig. 1), glucose will contact the electrode surface and more easily producing a direct-oxidation signal.

Fig. 4 shows the calibration curves of a set of electrodes similar to those shown on Fig. 3.a but with no immobilized enzyme. The observed current signal in this case is due to direct electrochemical oxidation of glucose on the electrode surface. Comparison of Fig. 3.a and Fig . 4 illustrate the catalytic effect of the enzyme on glucose oxidation. 


\section{Life Time of the Sensors}

Table 2. compares the sensitivity of the electrodes coated with Stöber glass layer with different bead radii as a function of the storage time. From the Table it can be seen that up to 5 days after immobilization, the value of the response did not change dramatically. The electrodes coated with $20 \mathrm{~nm}$ Stöber glass beads showed the highest response followed by that with $45 \mathrm{~nm}, 70 \mathrm{~nm}$ and $100 \mathrm{~nm}$ Stöber glass beads in the coating layer respectively. However, 2 weeks after immobilization, the response order changed: the electrode with $70 \mathrm{~nm}$ Stöber glass beads showed the highest response signal, followed by electrodes coated with $20 \mathrm{~nm}, 100 \mathrm{~nm}$ and $45 \mathrm{~nm}$ glass beads in that order.

TABLE 2. Comparison of the initial sensitivity of the electrodes with time

\begin{tabular}{|c|c|c|c|c|c|c|c|c|}
\hline Day & $\rightarrow 1$ & 3 & 5 & 9 & 14 & 18 & 35 & 53 \\
\hline \multicolumn{3}{|c|}{$\begin{array}{l}\text { Diameter } \\
\text { (nm) } \\
\downarrow\end{array}$} & \multicolumn{4}{|c|}{ Initial Sensitivity (nA.dL/mg) } & & \\
\hline 20 & 14.8 & 9.75 & 8.75 & 4.00 & 3.75 & 2.50 & 3.00 & \\
\hline 45 & 10.0 & 6.25 & 5.25 & 2.25 & 1.75 & 1.25 & 1.00 & 0.96 \\
\hline 70 & 7.50 & 6.50 & 5.25 & 5.25 & 5.00 & 5.50 & 6.00 & 4.00 \\
\hline 100 & 5.75 & 6.25 & 4.25 & 3.25 & 3.00 & 2.25 & 2.00 & 1.90 \\
\hline
\end{tabular}

Fig. 5 shows the life time curves of the sensors. From the Figure it can be seen that in the beginning of the testing period the response of the electrodes decreased quickly, except for the electrode with $70 \mathrm{~nm}$ Stöber glass beads. A possible explanation of this could be some release during the first days of 
experiments of enzyme weakly bound to the glass beads. Deactivation (poisoning) of the platinum working electrode surface during the test by oxidation products could also contribute to the decrease in the overall electrode sensitivity.

After 10 days the responses tended to become stable. The electrode with 70 $\mathrm{nm}$ Stöber glass beads demonstrate the most stable long-term performance. It can be seen from the Fig. 5 that the signal of this electrode was stable over a 50 days period..The response sensitivity was within the acceptable limits during that period of testing. It is possible that the electrodes with $70 \mathrm{~nm}$ bead radius offer the optimum porosity and surface area for the enzyme immobilization. On the other hand, the electrode with $20 \mathrm{~nm}$ Stöber glass beads demonstrated highest initial signal values, but decreased to a lowest value of the response during the first week. This is probably because the cracks on this electrode surface were the largest. Hence, the barrier to hydrogen peroxide and glucose was smaller than that of other electrodes. Also, since the porosity was the smallest of the four electrodes, the enzyme penetration was the least. Therefore, the exposed enzyme on the surface of beads could have easily been washed off.

The electrode coated with Stöber glass with $45 \mathrm{~nm}$ bead radius showed the second greatest decrease. Electrodes coated with Stöber glass with beads of radius $100 \mathrm{~nm}$ were more stable than the electrodes coated with $20 \mathrm{~nm}$ and $45 \mathrm{~nm}$ beads. The possible reason may be the better uniformity of the layer and porosity. From the data we can see that the best porosity for enzyme immobilization was shown by the electrode with beads radius of $70 \mathrm{~nm}$. The change in the order of response could have been due to the release of enzyme into the bulk solution either due to poor binding of enzyme onto the matrix, or due to the cracks in the glass coating layer. 
Measurement of Glucose Concentration in Blood Plasma

The evaluation of the enzyme electrode performance in blood plasma can be used as an initial interference test. A calibration curve in bovine blood plasma is obtained by a procedure similar to that when phosphate buffer solution is used. Fig. 6 presents a comparison between the calibration curve in bovine blood plasma (curve 2) and two calibration curves in phosphate buffer solution, obtained before (curve 1) and after several hours of operation in undiluted blood plasma (curve 2) for an electrode with bea radius $70 \mathrm{~nm}$. The calibration curve in bovine blood plasma starts from a concentration of glucose of $113 \mathrm{mg} / \mathrm{dL}$ (the actual concentration of the sample) to avoid dilution. An extrapolation of the calibration curve in blood plasma (the part of curve 2 shown by the dotted line) was used for the estimation of glucose concentration lower than $113 \mathrm{mg} / \mathrm{dL}$. Variation of the glucose concentration in the plasma is achieved by addition of small aliquot volumes of glucose stock solution to avoid dilution.

Glucose concentration in a serum sample (glucose level $113 \mathrm{mg} / \mathrm{dL}$ ) has been monitored by the enzyme electrode for 6 hours (in vitro) with no noticeable change in the electrode response. During the following 12 hours of continuous glucose monitoring with the same electrode the signal decreased by $15 \%$ of its initial value. After this test a calibration curve of this electrode in phosphate buffer glucose solution was obtained and the results are shown on Fig. 6 , curve 3 .

The sensitivity of the electrode in blood plasma decreases by about $15 \%$ with respect to the initial slope of the calibration curve obtained before the serum test (compare curves 1 and 2 in Fig. 6).

The decrease of glucose current response in undiluted serum and in phosphate buffer after the serum tests is probably caused by deposition of proteins from the plasma onto the glass bead coated electrode surface. This deposition can be consider irreversible because the electrode properties remain practically constant 
in tests (in phosphate buffer or in blood plasma) afterwards. It can be hypothesized that this deposition caused an increase of the diffusion limitation of dissolved oxygen and glucose leading to a decrease in the current signal.

Several whole bovine blood samples with known glucose concentrations (measured using routine clinical methods) were obtained. From these samples blood plasma was prepared by centrifugal separation. The amperometric response of the enzyme electrode with bead radius $70 \mathrm{~nm}$, to the glucose levels in blood plasma was obtained and the concentration of glucose estimated using the electrode calibration curve in blood plasma (Fig. 6, curve 2). These glucose concentrations, measured by the electrode, are shown in Fig. 7 together with the data for the same samples measured by conventional method. The correlation between the two sets of measurements is characterized by the slope 0.896 with a regression coefficient 0.983 (number of samples was 11).

\section{CONCLUSION}

The glass-coated needle-type electrode was made by using silanization followed by cross-linking the enzyme onto glass beads of four different sizes: 20 $\mathrm{nm}, 45 \mathrm{~nm}, 70 \mathrm{~nm}, 100 \mathrm{~nm}$. Of the four electrodes, the electrode coated with Stöber glass with $70 \mathrm{~nm}$ bead radius showed the best characteristics in stability and sensitivity. Preliminary tests of the enzyme electrode coated with $70 \mathrm{~nm}$ glass beads in undiluted blood plasma suggest that biosensors based on such electrodes can be used for glucose measurements in physiological fluids. Further experiments need to be performed to improve the performance of the biosensor. This includes improvement in the control of porosity, surface pretreatment and particularly avoidance of cracking of the Stöber glass layer. 


\section{ACKNOWLEDGEMENTS}

This work was partially supported by Sandia National Laboratories and in part by a grant from the US Army Research Office.

Our gratitude to Ms. Carol S. Ashley for the Stöber glass beads preparation.

\section{REFERENCES}

1. J.C.Pickup, Diabetes Care 16, 535 (1993)

2. D. S.Bindra,Y.Zhang, G. S.Wilson, Anal. Chem. 63, 1692 (1991)

3. S.J.Churchouse, W.H.Mullen, F.H.Keedy, Anal. Proc. 23, 146 (1986)

4. M.Shichiri, R.Kawamori, K.Yamasaki, N.Hakui, H.Abe, Lancet 20, 1129 (1982)

5. D.Moatti-Sirat, F.Capron, V.Poitout, G.Reach, D.S.Bindra, Y.Zhang, G.S.Wilson, D.R.Thevenot, Diabetologia 35, 224 (1992)

6. M.Shichiri, Y.Kawamori, N.Hakui, H.Abe, Horm. Metab. Res. 20, 17 (1988)

7. I.Abdel-Hamid, P.Atanasov, E.Wilkins, Analytical Letters 27, 1453 (1994)

8. C.J.Brinker, G.W.Scherer, Sol-Gel Science. Academic Press: NY, 1990

9. D.Avnir, D.Levy, R.Reisfeld, J. Phys. Chem. 88, 5956 (1984)

10. I.Kuselman, B.I.Kuyavskaya, O.Lev, Anal. Chim. Acta. 256, 65 (1992)

11. D.Avnir, S.Braun, M.Ottolenghi, ACS Symp.Series 499, 384 (1992)

12. S.Braun, S.Rapport, R.Zusman, D.Avnir, M.Ottolenghi, Mater.Lett. 10, 1 (1990)

13. P.Audebert, C.Demaille, Chem. Mater. 5, 911 (1993)

14. S.A.Yamanakana, F.Nishida, L.M.Ellerby, C.Nishida, B.Dunn, J.Valentine, J.L.Zink,Chem. Mater. 4, 495 (1992)

15. V.Glezer, O.Lev, J. Am. Chem. Soc. 115, 2533 (1993)

16. M.Tsionsky, G.Gun, V.Glezer, O.Lev, Anal. Chem. 66, 1747 (1994)

17.Y.Tatsu, K.Yamashita, M.Yamaguchi, S.Yamamura, H.Yamamoto, S.Yoshikawa, Chemistry Letters, 1615 (1992)

18. O.Dvorak, M.K.Armond, J. Phys. Chem. 97, 2646 (1993)

19. S.Braun, S.Shtelzer, S.Rappoport, D.Avnir, M.Ottolenghi, M. J. Noncryst. Solids 147/148, 739 (1990)

20. G.C.Frye, A.JRicco, S.J.Martin, C.Brinker, J. Mat. Res. 121, 349 (1984)

21. W.Stöber, A.Fink, E.Bohn, J. Colloid and Int. Sci. 26, 62 (1968)

22. C.J.Brinker, R.Sehgal, S.L.Hietala, R. Deshpande, D.M.Smith, D.Loy, C.S.Ashley, J.Membrane Science 94, 85 (1994) 


\section{LEGENDS FOR THE FIGURES}

FIG. 1 SEM micrographs of the Stöber glass beads coated on the platinum electrode. Glass bead radius is listed on the right upper corner of each of the photographs

FIG. 2 Schematic of the glass-bead-coated glucose enzyme electrode

FIG. 3 (a) Calibration curves of the glucose enzyme electrodes coated with Stöber glass beads with different radius: non-coated electrode (1); bead radius of $20 \mathrm{~nm} \mathrm{(2);45} \mathrm{nm} \mathrm{(3);} 70 \mathrm{~nm}(4) ; 100 \mathrm{~nm}(5)$. Curves correspond to the initial tests of each electrode.

(b) Eadie-Hofstee plots of the data presented on Fig. 3.a.

FIG. 4 Calibration curves for direct electrochemical (non-enzymatic oxidation) of glucose on electrodes coated with Stöber glass beads with different radius: $20 \mathrm{~nm}(1) ; 45 \mathrm{~nm} \mathrm{(2);70} \mathrm{nm} \mathrm{(3);} 100 \mathrm{~nm}$ (4).

FIG. 5 Lifetime curves of the enzyme electrodes coated with Stöber glass beads with different radius: electrode signal at glucose concentration of $120 \mathrm{mg} / \mathrm{dL}$ as a function of electrode storage time. 

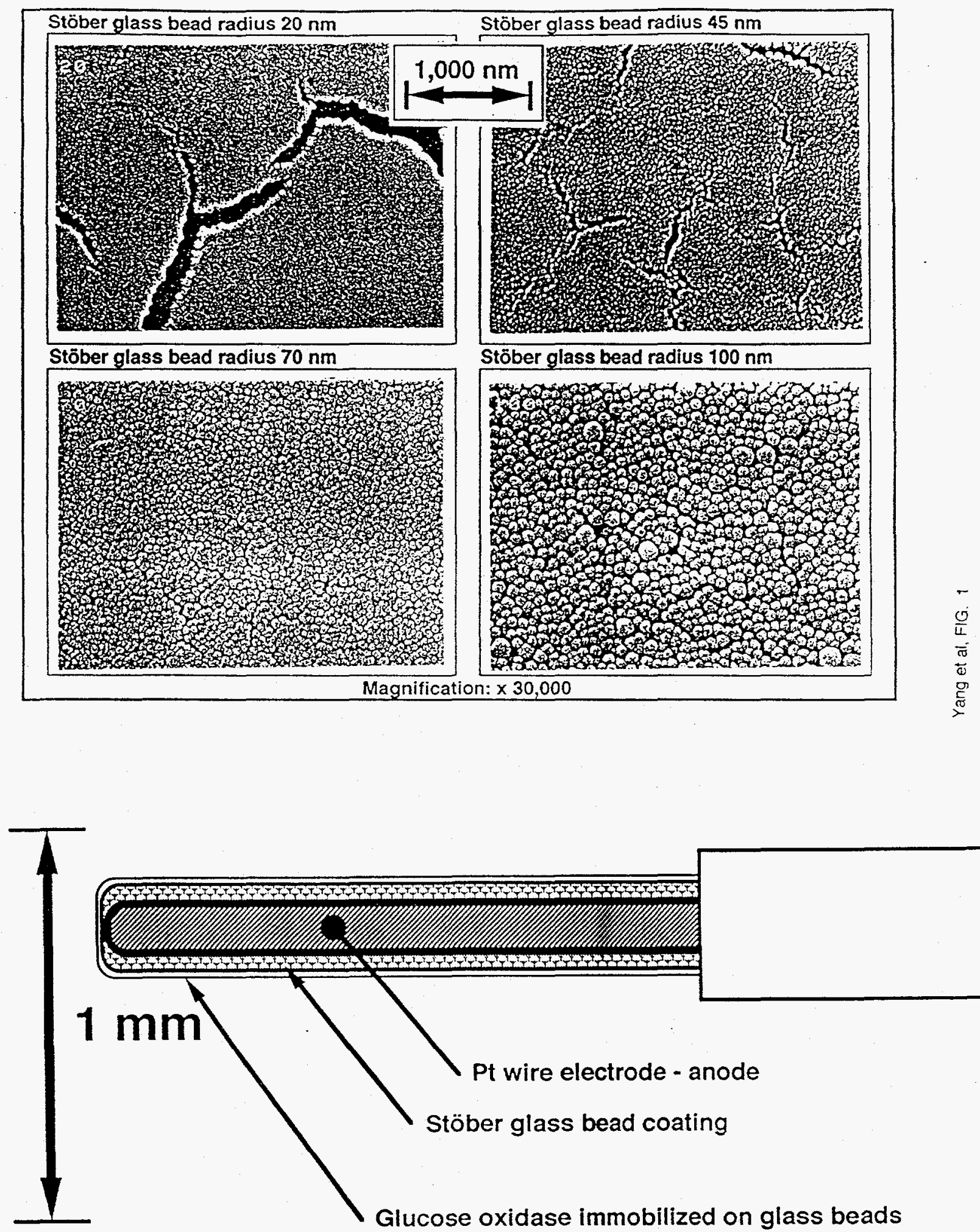

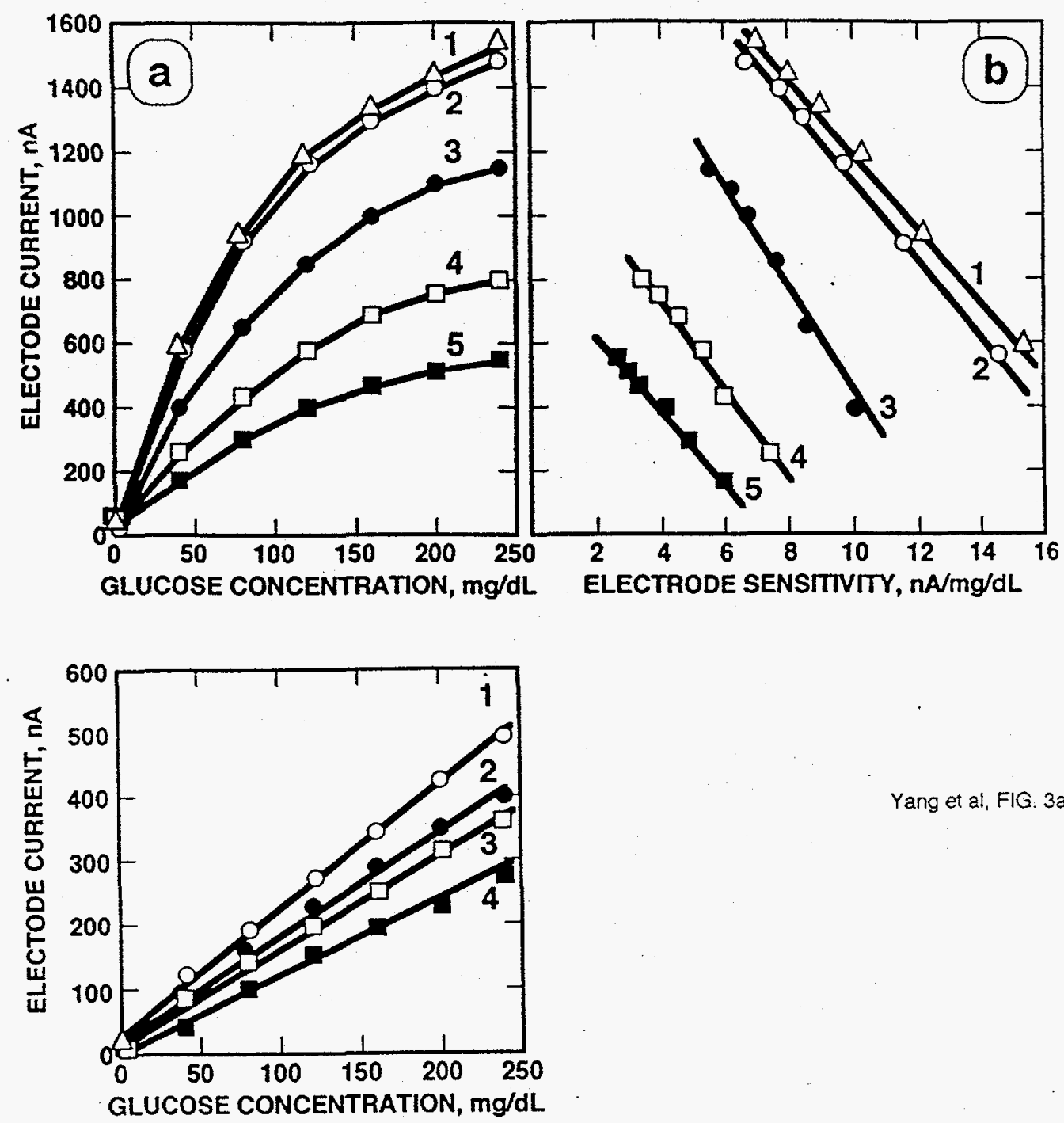

Yang et al, FIG. $3 a \& 3 b$

Yang et al, FiG. 4

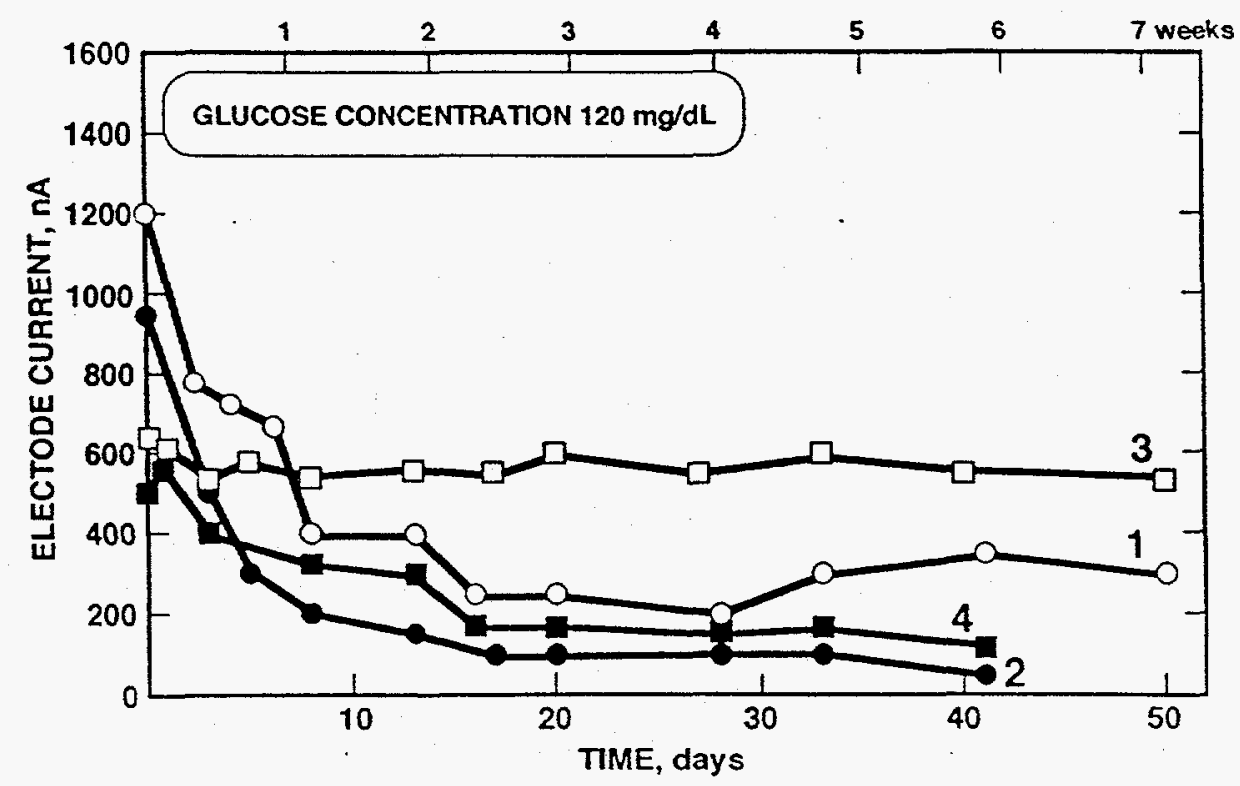




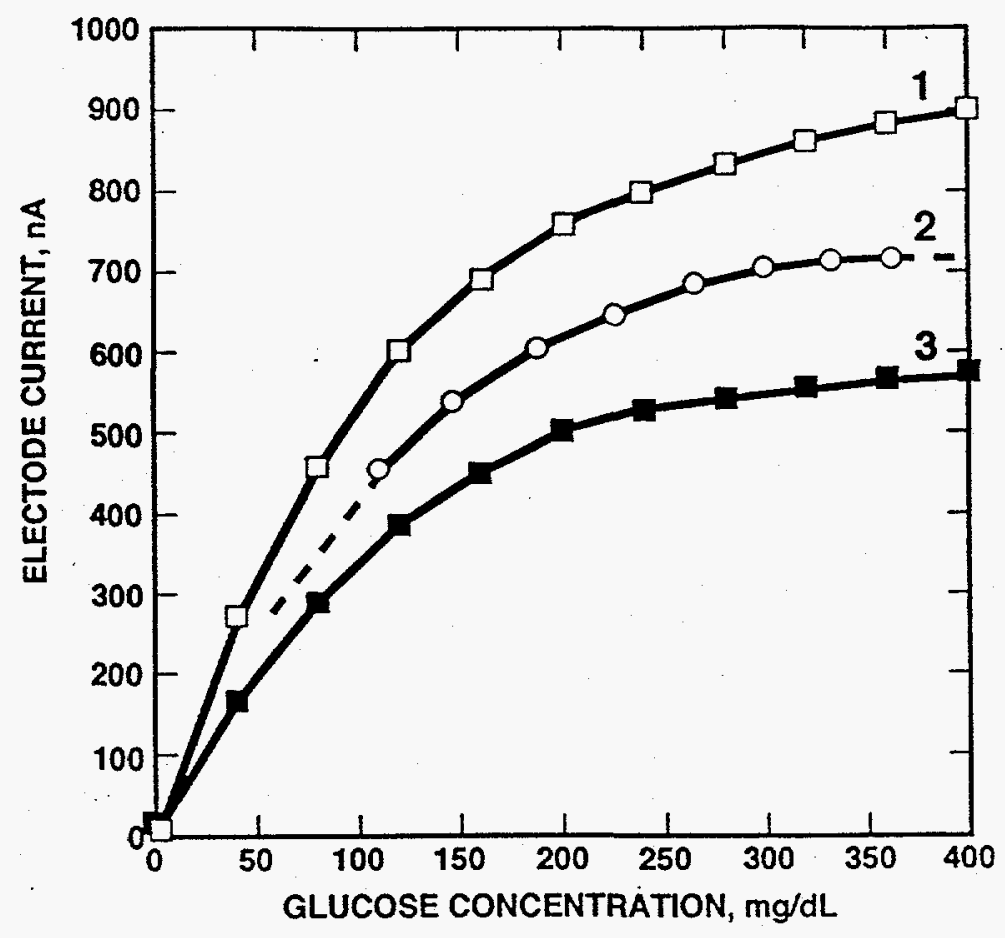

Yang et al, FIG. 6

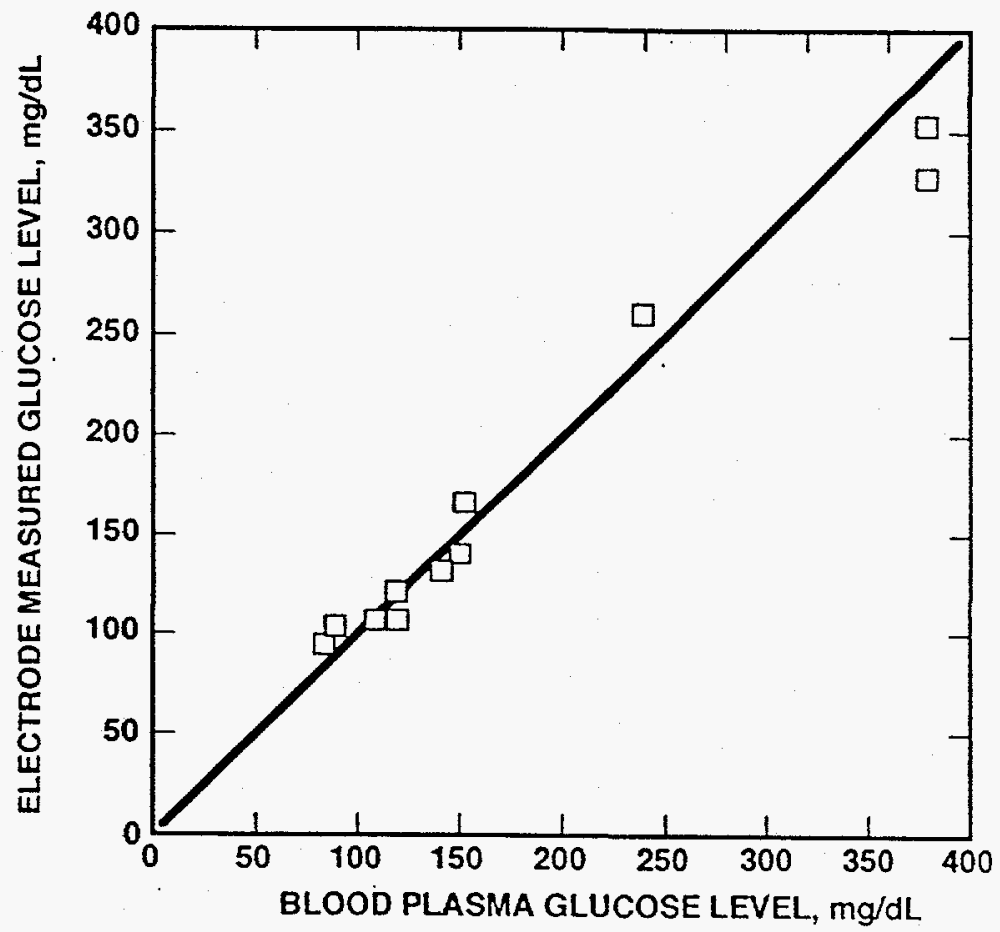

Yang et al, FIG. 7 


\section{Appendix B:}

A Patent Disclosure, SD-4971, entitled: "Planar Microelectronic Parallel Processing Cell Sorting Device" by Robert C. Hughes. 
PATENT DISCLOSURE SD-4971

$12 / 30 / 90$

Planar Microelectronic Parallel Processing Cell Sorting Device

BACKGROUND

One new area of biotechnology is called "Applied Molecular Evolution" which is described in some detail in an article in the "New Scientist" (1). As explained in the article, progress in this new field is being hindered by a lack of instrumentation. A prominent problem is locating a particular bacterium, virus or biopolymer in a group which may contain as many as les other, uninteresting molecules or organisms. Any serial method, which look at one organism at a time which they are flowed past a port, would be too slow ( at one organism per second it would take a few years for just one batch). The invention described here builds on an earlier disclosure we submitted, "Ultradetection of molecules with an Immuno-Field Effect Transistor" (2). We have found that the solution to several of the problems posed by the biochemists can be found by exploiting planar micro-electronic technology to form very large numbers of individual biosensors on one chip.

DESCRIPTION OF THE INVENTION

The basis for the parallel processing chip is to use $\mathrm{Si}$ integrated circuit technology to make a planar array of biosensors in a very simple way. Following the design of the individual biosensor (see disclosure), a thin polymer film/membrane (about 1 micron thick) is spread over the entire SiN surface. Embedded in this film is the bound enzyme (e.g. urease) and if an aqueous soln. containing urea is placed on the structure, very fast $\mathrm{pH}$ changes occur everywhere in the planar dimension. A "pixel" is defined as a region in the plane where a a local change in $\mathrm{pH}$ can be distinguished from a neighboring pixel where no change has taken place. The minimum size of the pixel gives the resolution of the array. The inhibiting antibody is then spread over the array and each pixel is inhibited from producing a $\mathrm{pH}$ change from the substrate chemical (e.g. urea). An agar solution with bugs in it is spread over the planar array. The bugs producing the chemical that binds the antibody causes that pixel in the array to change $\mathrm{pH}$. The pixel is located by one of several means, including light induced photovoltage. An automated pipette then goes to that location and removes the bug producing the chemical of interest and isolates it for further multiplication. 


\title{
Planar Microelectronic Parallel Processing
}

\author{
Cell Sorting Device
}

computer driven point light source

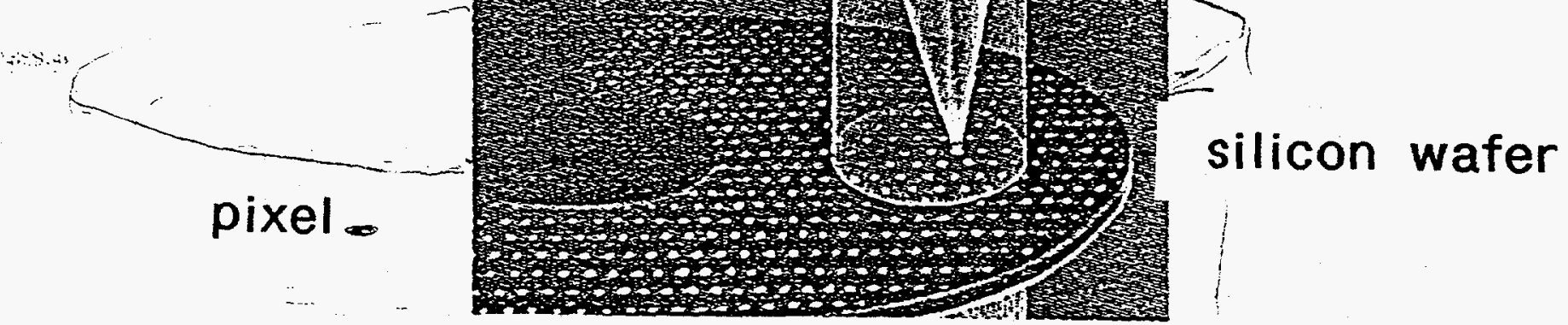

polymer film with immobilized enzyme

silicon nitride

silicon dioxide

low doped silicon photoactive layer

ohmic contact to silicon wafer

side view of individual pixel 


\section{Distribution List}

\begin{tabular}{|c|c|c|}
\hline Copies & Mail Stop & Addressee \\
\hline$\overline{10}$ & MS1425 & R. C. Hughes, 1315 \\
\hline 1 & MS9018 & Central Technical Files, 8523-2 \\
\hline 5 & MS0899 & Technical Library, 4414 \\
\hline 2 & MS0619 & $\begin{array}{l}\text { Review and Approval Desk, } 12630 \\
\text { for DOE/OSTI }\end{array}$ \\
\hline 2 & MS0188 & LDRD Office, 4523 \\
\hline
\end{tabular}

